\title{
Efek Penggunaan Vortex Generator Terhadap Karakteristik Aliran pada Airfoil NACA 43018
}

\author{
Setyo Hariyadi S.P. ${ }^{1}$, Wawan Aries Widodo ${ }^{2}$ \\ Laboratorium Mekanika dan Mesin Fluida \\ Jurusan Teknik Mesin, Fakultas Teknologi Industri, Institut Teknologi Sepuluh Nopember \\ (ITS) \\ Jl. Arief Rahman Hakim, Surabaya 60111 Indonesia \\ e-mail: hudzaifahsetyo@gmail.com
}

\begin{abstract}
ABSTRAK
Perancangan pada sayap pesawat terbang bertujuan menghasilkan lift yang setinggi-tingginya dan drag yang sekecil-kecilnya. Penundaan separasi menjadi hal yang penting dan sangat mempengaruhi kinerja aerodinamika-nya. Vortex generator merupakan salah satu alat yang memiliki pengaruh signifikan terhadap performasi tersebut. Dengan penambahan vortex generator ini separasi aliran dapat tertunda dan performansi sayap dapat meningkat.

Topik yang dikaji dalam penelitian ini adalah aliran pada airfoil NACA 43018 dengan penambahan vortex generator. Tujuan penelitian ini adalah untuk membandingkan karakteristik aliran fluida plain wing dan dengan penambahan vortex generator. Profil vortex generator yang digunakan adalah flat plate vortex generator dengan konfigurasi straight dan ditempatkan pada $\mathrm{x} / \mathrm{c}=10 \%$ dan $20 \%$ arah chord line dari leading edge. Variasi yang digunakan adalah bilangan Reynolds (Re), sudut serang $(\alpha)$ dan peletakan vortex generator pada airfoil. Kecepatan freestream yang digunakan yaitu kecepatan $12 \mathrm{~m} / \mathrm{s}$ atau $\operatorname{Re}=7,65 \mathrm{x}$ $10^{5}$ dan kecepatan $17 \mathrm{~m} / \mathrm{s}$ atau $R e=9 \times 105$, dan pada sudut serang $(\alpha) 0^{\circ}, 3^{\circ}, 6^{\circ}, 9^{\circ}, 12^{\circ}, 15$ ${ }^{\circ}, 19^{\circ}$, dan $20^{\circ}$. Parameter yang dievaluasi meliputi koefisien tekanan (Cp), profil kecepatan, gaya lift, gaya drag, dan rasio $\mathrm{C}_{\mathrm{L}} / \mathrm{C}_{\mathrm{D}}$.

Hasil penelitian ini menunjukkan bahwa terjadi peningkatan performansi dari airfoil NACA 43018 dengan penambahan vortex generator dibandingkan dengan tanpa vortex generator. Adanya vortex generator, meningkatkan Turbulent Kinetic Energy dan mempercepat perubahan dari aliran laminar ke turbulen. Separasi dapat tertunda dengan adanya vortex generator.
\end{abstract}

Kata kunci: airfoil NACA 43018, vortex generator, koefisien tekanan, gaya lift, gaya drag

\section{PENDAHULUAN}

Gaya angkat pada airfoil terjadi karena adanya tekanan tinggi pada lower surface dan tekanan lebih rendah pada upper surface. Sesaat setelah melewati leading edge, aliran dipercepat sehingga gradien tekanan bernilai negatif. Kemudian setelah kontur puncak airfoil, aliran diperlambat dan gradien tekanan bernilai positif. Ketika momentum aliran tidak mampu melawan adverse pressure gradien dan tegangan geser maka terjadilah separasi. Adanya separasi ini sangat merugikan karena dapat menurunkan lift force dan menaikkan drag force terutama pada sudut serang tinggi. Oleh sebab itu diperlukan modifikasi pada airfoil seperti menggunakan vortex generator yang dapat menunda separasi sehingga dapat 
meningkatkan efisiensi. Vortex generator $(\mathrm{VG})$ adalah suatu alat yang dapat mempercepat terjadinya transisi dari laminar boundary layer menjadi turbulen boundary layer. Ada berbagai jenis vortex generator antara lain vane, delta wing, dan triangular. Aliran turbulen boundary layer yang dibangkitkan ini diharapkan dapat meningkatkan momentum aliran sehingga lebih mampu menahan adverse pressure gradien dan menunda separasi.

Lin [1] memperkenalkan vortex generator pada penelitiannya terhadap separasi pada diffuser. Adanya vortex generator ini ternyata dapat meningkatkan momentum yang signifikan pada aliran dengan didapatkan $C_{D}$ yang lebih rendah meskipun dengan perbandingan titik stall pada sudut serang yang sama. Selain itu, efektivitas vortex generator juga dipengaruhi oleh ketinggian dari vortex generator tersebut. Diharapkan ketinggian vortex generator adalah sebesar boundary layer thickness, $\delta$. Sementara itu, Anand et al [2] meneliti efektifitas vortex generator jenis triangle vortex generator yang diletakkan pada $10 \%$ chord length pada airfoil jenis NACA 0012. Berdasarkan penelitian ini didapatkan hasil yaitu penggunaan vortex generator dapat menunda separasi pada dinding airfoil. Zhen [3] juga melakukan penelitian terhadap beberapa bentuk vortex generator dengan ketinggian yang berbeda dan didapatkan bahwa bentuk rectangular dan curve-edge vortex generator memiliki efektifitas yang lebih tinggi daripada triangular dalam menaikkan gaya angkat (lift force).

Pada penelitian kali ini, akan digunakan airfoil NACA 43018 dengan vortex generator berupa rectangular flat plate dengan susunan straight. Airfoil NACA 43018 digunakan pada wing pesawat ATR 72 baik seri 500 maupun 600. Pesawat jenis ini di Indonesia dioperasikan oleh Garuda Indonesia dan Lion Air untuk rute-rute pendek misalnya Surabaya-Jogjakarta dan Surabaya-Banyuwangi. Dengan adanya vortex generator ini diharapkan dapat menaikkan momentum aliran di dekat dinding airfoil sehingga dapat lebih tahan terhadap adverse pressure gradien dan menunda separasi. Dengan tertundanya separasi akan menaikkan lift force dan menurunkan drag force pada airfoil sehingga dapat meningkatkan performansi airfoil tersebut [4]. Dengan performa airfoil yang baik akan menghemat bahan bakar pesawat tersebut saat beroperasi

\section{METODE PENELITIAN}

Penelitian numerik dilakukan dengan menggunakan metode Computational Fluid Dynamics (CFD) dengan software Fluent 6.3.26. dan dengan software GAMBIT 2.4.6 dan Solidwork 2015 untuk membuat model awal dan melakukan diskritisasi (meshing) pada model tersebut. Hasil post procession akan menggunakan software Techplot 360 EX. Geometri model dibuat melalui software Gambit. Gambar 1 adalah model dari benda uji beserta test section dari simulasi numerik yang dilakukan. Benda uji yang dimodelkan pada gambar 2.

Profil airfoil yang digunakan dalam penelitian ini adalah dua airfoil tipe NACA 43018 dimana masing-masing adalah plain airfoil dan airfoil dengan vortex generator. Jenis vortex generator yang digunakan yaitu rectangular flat plate dengan konfigurasi straight seperti yang ditunjukkan pada gambar 1. 


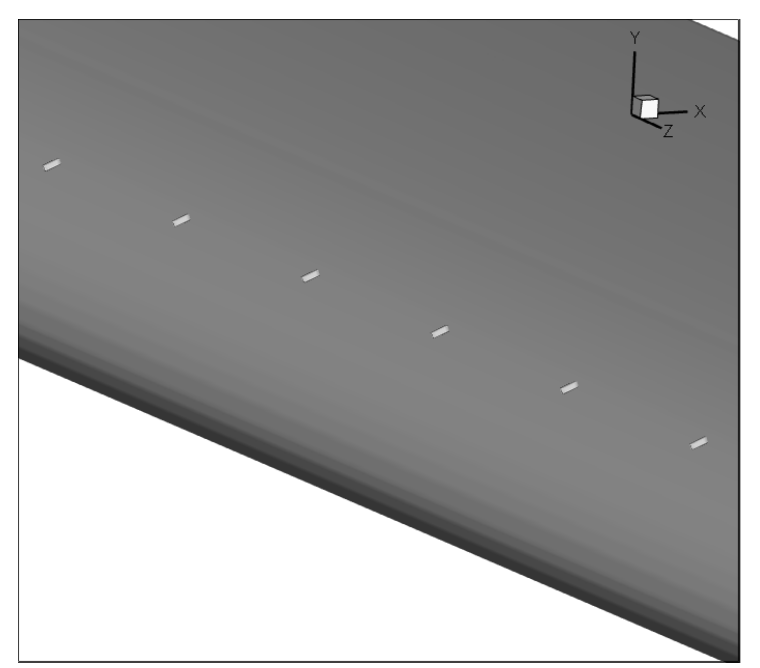

Gambar 1. Rectangular flat plate vortex generator

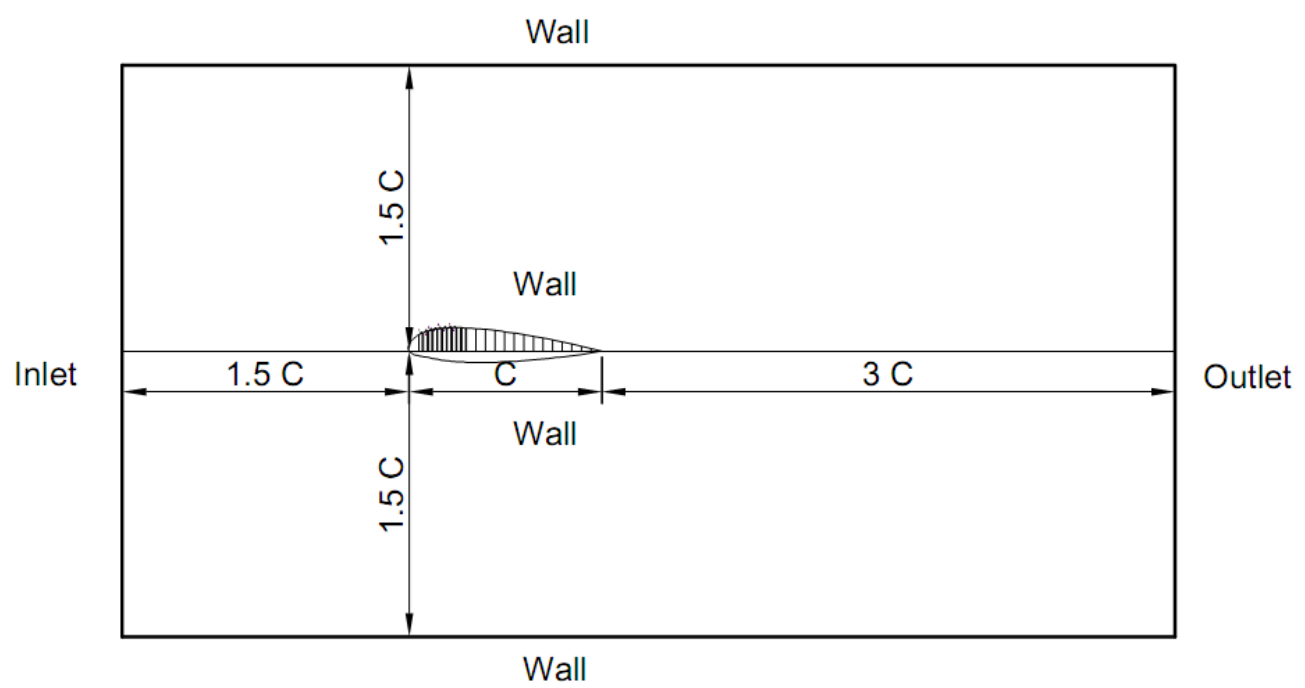

Gambar 2. Sketsa pemodelan penelitian [6]

Tabel 1. Langkah-langkah pada fluent dan inputannya

\begin{tabular}{|l|l|l|}
\hline \multicolumn{1}{|c|}{ Langkah } & & \multicolumn{1}{c|}{ Input } \\
\hline Boundary Condition & Airfoil & Wall \\
& Dinding & Wall \\
& VG & Wall \\
\cline { 2 - 3 } & Inlet & Velocity inlet $(12$ dan $17 \mathrm{~m} / \mathrm{s})$ \\
\cline { 2 - 3 } & Outlet & Outflow \\
\cline { 2 - 3 } & Interior & Interior \\
\hline Models & & $\mathrm{k}-\varepsilon$ Realizable \\
\hline Material & Densitas $(\rho)$ & $1.18 \mathrm{~kg} / \mathrm{m}^{3}$ \\
\cline { 2 - 3 } & Viskositas $(\mu)$ & $1.85 \times 10^{5} \mathrm{~kg} / \mathrm{m} . \mathrm{s}$ \\
\hline \multirow{2}{*}{ Operating Condition } & & $\begin{array}{l}\text { Temperature }=30^{\circ} \mathrm{C} \\
\text { Pressure }=10^{5} \mathrm{~Pa}\end{array}$ \\
\hline \multirow{2}{*}{ Solution } & & $\begin{array}{l}\text { Second-order upwind untuk momentum, } \\
\text { Pressure Velocity Coupling PISO. }\end{array}$ \\
\hline Monitor Residual & & $10^{-6}$ \\
\hline
\end{tabular}

Dalam penggunaan Fluent 6.3.26 memerlukan keakuratan data baik pada langkah post processing maupun preprocessingnya. Langkah grid independensi diperlukan untuk 
menentukan tingkat serta struktur grid terbaik dan terefisien agar hasil pemodelan mendekati sebenarnya.

Grid independensi ini dilakukan untuk mendapatkan jumlah meshing yang cenderung konstan sehingga didapatkan Pada grid independensi ini, dilakukan pembagian jumlah meshing ke dalam 4 jenis, kemudian dari jenis meshing ini akan dicari besarnya selisih nilai terkecil dari setiap meshing dengan membandingkan grafik $C_{D}$ Numerik. Nilai $C_{D}$ dari grid indepedensi akan ditampilkan pada tabel 2.

Tabel 2 Analisa grid independensi Airfoil 430183 Dimensi tanpa Vortex Generator dengan Re = $7,65 \times 10^{5}$.

\begin{tabular}{|c|c|c|}
\hline Jenis Meshing & Jumlah Node & $C_{D}$ \\
\hline Meshing A & 639.000 & 0.15 \\
\hline Meshing B & 1.632 .000 & 0.216 \\
\hline Meshing C & 1.662 .642 & 0.297 \\
\hline Meshing D & 1.814 .400 & 4.32 \\
\hline
\end{tabular}

Tabel 2 menunjukkan grid independensi pada plain airfoil. Berdasarkan tabel 2 nilai $C_{D}$ yang cenderung konstan terjadi pada Meshing A dan Meshing D. Salah satu pertimbangan dalam melakukan simulasi numerik adalah waktu dan memori yang digunakan, maka meshing yang digunakan untuk simulasi selanjutnya adalah meshing A.

\section{HASIL PENELITIAN DAN PEMBAHASAN}

\section{Visualisasi Aliran}

Pada bagian ini ditampilkan beberapa hasil visualisasi aliran hasil post processing pemodelan numerik dengan turbulence model $k$ - $\varepsilon$ Realizable. Visualisasi aliran yang akan dijelaskan diantaranya velocity vector, velocity Pathline serta kontur turbulensi yang berguna untuk melengkapi informasi mengenai hasil pemodelan numerik yang telah dijelaskan sebelumnya.

\section{Kontur Kecepatan dan Pathline pada Plain Airfoil}

Pada gambar 3 merupakan visualisasi vektor kecepatan pada sudut serang $\alpha=0^{0}$. Separasi akan semakin maju dekat leading edge seiring dengan bertambahnya sudut serang dan bilangan Reynolds yang kecil pada sudut serang yang sama. Separasi menentukan besar kecilnya wake, apabila separasi yang terjadi lebih awal maka wake yang terbentuk akan semakin besar. Pada gambar 3, $\alpha=19^{0}$ terlihat bahwa titik separasi semakin maju mendekati leading edge. 


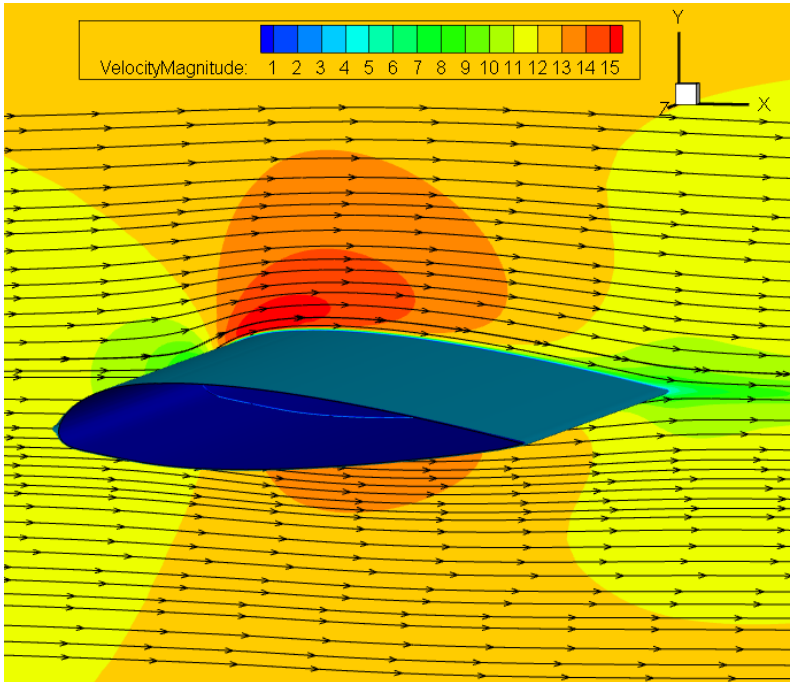

(a)

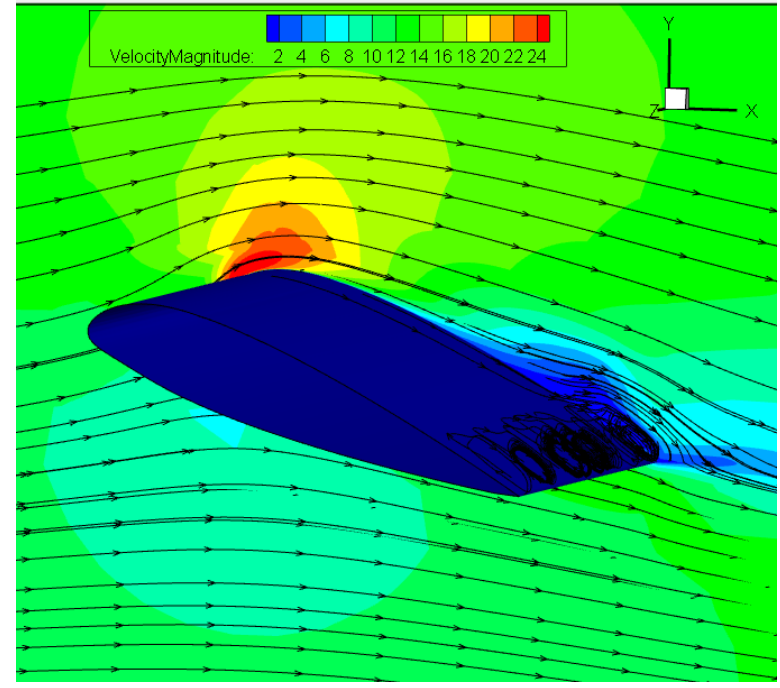

(b)

Gambar 3. Visualisasi kontur kecepatan dan Pathline plain Airfoil pada sudut serang $\alpha=0^{0}$ (a) dan $\alpha$ $=19^{0}(\mathrm{~b})$ pada $\operatorname{Re} 7,65 \times 10^{5}$.

\section{Karakteristik Aliran Plain Airfoil 3D dan Airfoil dengan Vortex Generator}

\section{Vektor Kecepatan pada Plain Airfoil 3D dan Airfoil dengan Vortex Generator}

Pengaruh penggunaan vortex generator ditunjukkan pada gambar 4 untuk sudut serang 19 . Pada gambar 4.a ditunjukkan profil kecepatan pada plain airfoil $\mathrm{z}=2$ (midspan), $\mathrm{x}=2$. Profil kecepatan pada bagian atas cenderung berkurang menandakan pengaruh gaya geser dan adverse pressure gradient. Sedangkan pada posisi yang sama pada gambar 4.b dimana diambil titik $\mathrm{z}=1,9075, \mathrm{x}=2$ yaitu daerah di belakang vortex generator $\mathrm{x} / \mathrm{c}=0,1$ maka profil kecepatan cenderung ada perbaikan bentuk ke kotak yang menandakan momentum hasil penempatan vortex generator mampu mengatasi gaya geser dan adverse pressure gradient. Demikian juga pada gambar 4.c dimana diambil titik $\mathrm{z}=1,9075, \mathrm{x}=2$ yaitu daerah tepat di belakang vortex generator $\mathrm{x} / \mathrm{c}=0,2$ maka profil kecepatan cenderung berbentuk kotak yang menandakan momentum hasil penempatan vortex generator lebih mampu mengatasi gaya geser dan adverse pressure gradient.

Untuk melihat kontur kecepatan dan pengaruh penggunaan vortex generator pada pada sudut serang $15^{0}$ dan $19^{0}$ akan ditampilkan dalam bentuk 3D pada gambar 4 . Gambar 4 menunjukkan vektor kecepatan pada airfoil di daerah upstream dengan pemotongan pada area midspan. Pada plain airfoil $3 \mathrm{D}$ dengan sudut serang $3^{0}$ dengan penggunaan vortex generator $10 \%$ separasi mendekati trailing edge namun pengaruh yang dihasilkan tidak begitu signifikan hal ini dimungkinkan karena dengan adanya vortex generator menambah momentum aliran sehingga aliran masih mengikuti kontur bodi airfoil. Momentum aliran yang tinggi mampu melawan gaya geser dan adverse pressure gradient. Sedangkan pada 
airfoil dengan penambahan vortex generator sudut serang $0^{0}$ belum terlihat terjadi separasi hingga di daerah trailing edge. Hal ini disebabkan dengan adanya vortex generator menambah momentum aliran sehingga aliran masih mengikuti kontur bodi airfoil. Momentum aliran yang tinggi mampu melawan gaya geser dan adverse pressure gradient.

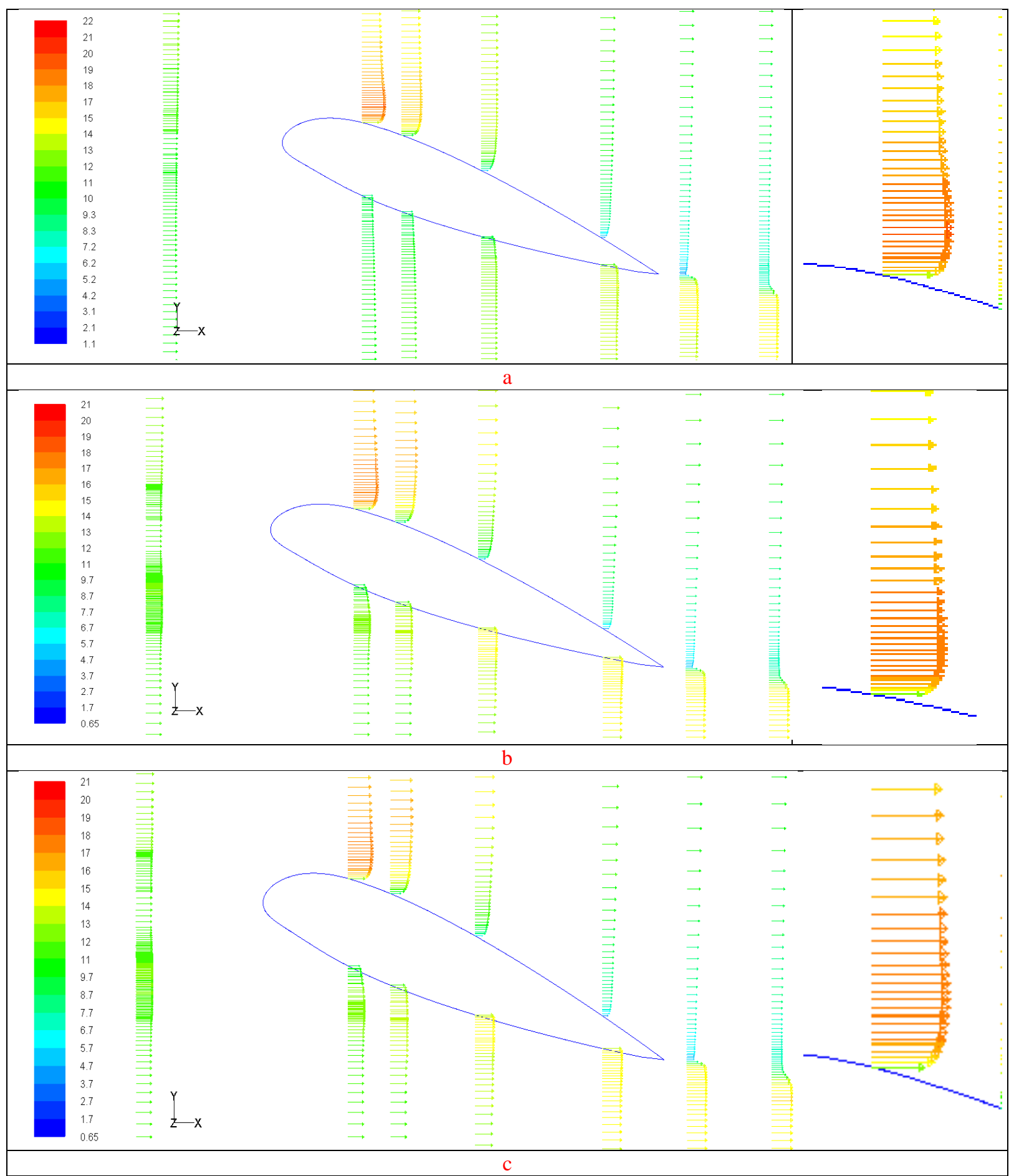

Gambar 4. Vektor Kecepatan pada plain airfoil 3D dengan Vortex Generator 10\% dan Vortex Generator 20\% pada serang $19^{0} \operatorname{Re} 7,65 \times 10^{5}$ 


\section{Kontur Turbulence Kinetic Energy pada Plain Airfoil 3D dan Airfoil 3D dengan Vortex Generator}

Pada bagian ini dibandingkan karakteristik Turbulence Kinetic Energy plain airfoil 3D dengan airfoil dengan penambahan vortex generator. Proses pembandingan dengan cara menampilkan visualisasi aliran berupa turbulent intensity. Konfigurasi yang ditampilkan yaitu pada $R e 7,65 \times 10^{5}$. Titik yang diamati adalah pada $\mathrm{x}=0,25$ yaitu tepat di belakang vortex generator.

Pada gambar 5.(a) Turbulence Kinetic Energy pada plain airfoil tampak perbedaan kontur warna pada permukaan airfoil. Pada $\mathrm{x}=0.1$ tampak warna biru muda dan semakin ke belakang menjadi lebih gelap yang menandakan bahwa turbulence kinetic energy pada permukaan semakin menurun. Namun di atas permukaan turbulence kinetic energy masih lebih tinggi dari permukaan airfoil. Hal ini dimungkinkan karena pada permukaan harus melawan tegangan geser dan adverse pressure gradient.

Pada gambar 5.(b) Turbulence Kinetic Energy dengan penempatan vortex generator $\mathrm{x} / \mathrm{c}=10 \%$ didapati lebih tinggi dari plain airfoil. Dengan adanya vortex generator maka Turbulence Kinetic Energy di permukaan airfoil lebih tinggi begitu juga pada $\mathrm{x}=0.25$. Di titik di atas permukaan juga lebih tinggi dari pada plain airfoil dilihat dari gradient warna. Hal ini dimungkinkan karena dengan adanya vortex generator, aliran yang bersentuhan dengan vortex generator mengalami perubahan arah ke arah radial sehingga menimbulkan vortex dan aliran bertransisi dari laminar boundary layer ke turbulence boundary layer sehingga lebih mampu melawan tegangan geser dan adverse pressure gradient.

Pada gambar 5. (c) Turbulence Kinetic Energy dengan penempatan vortex generator $\mathrm{x} / \mathrm{c}=20 \%$ didapati lebih tinggi dari penempatan plain airfoil namun lebih rendah dari penempatan vortex generator $\mathrm{x} / \mathrm{c}=10 \%$. Dengan adanya vortex generator maka Turbulence Kinetic Energy di permukaan airfoil lebih tinggi pada $\mathrm{x}=0.25$. Di titik di atas permukaan juga lebih tinggi dari pada plain airfoil dilihat dari gradient warna. Hal ini dimungkinkan karena dengan adanya vortex generator, aliran yang bersentuhan dengan vortex generator mengalami perubahan arah ke arah radial sehingga menimbulkan vortex dan aliran bertransisi dari laminar boundary layer ke turbulence boundary layer sehingga lebih mampu melawan tegangan geser dan adverse pressure gradient. 


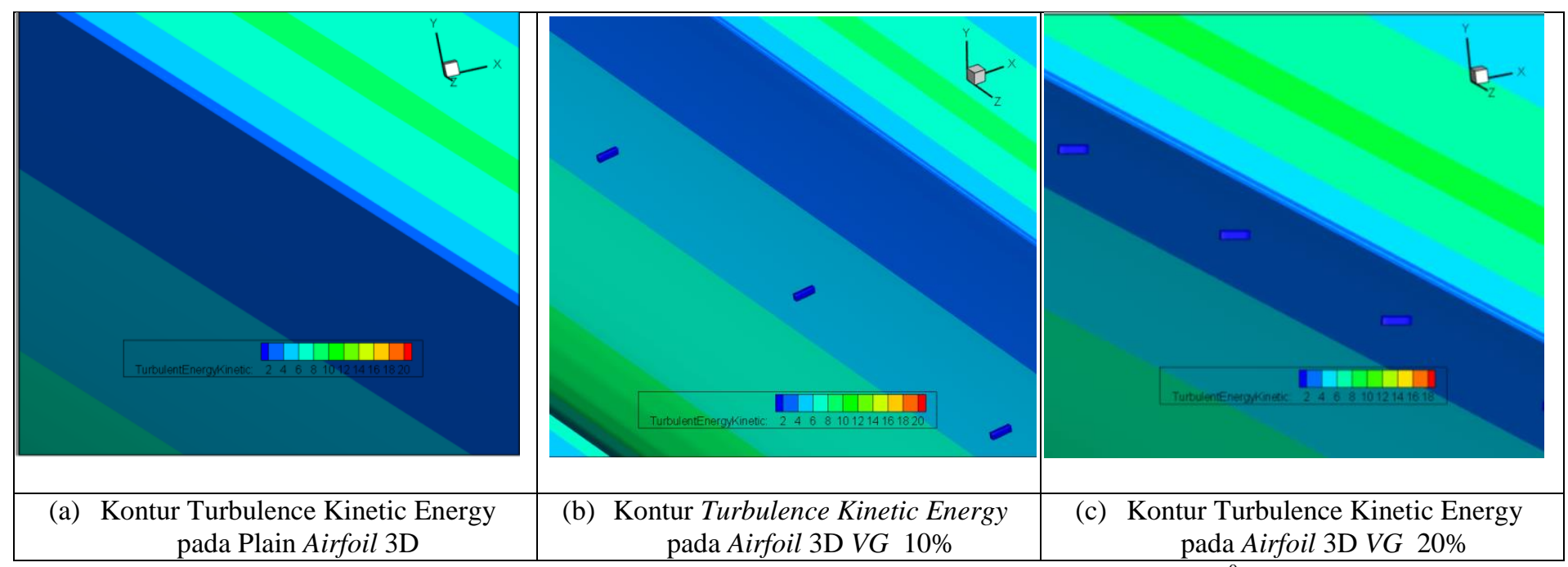

Gambar 5. Visualisasi perbandingan Turbulence Kinetic Energy pada sudut serang $19^{0}$ tanpa $V G, V G$ $10 \%$ dan $20 \%$

\section{Kontur Turbulensi pada Plain Airfoil 3D dan Airfoil 3D dengan VG}

Pada bagian ini dibandingkan karakteristik turbulensi plain airfoil 3D dengan airfoil dengan penambahan vortex generator. Proses pembandingan dengan cara menampilkan visualisasi aliran berupa turbulent intensity. Konfigurasi yang ditampilkan yaitu pada $\operatorname{Re} 9 \mathrm{x}$ $10^{5}$.

Gambar 6 merupakan visualisasi perbandingan turbulent intensity pada sudut serang $19^{0}$ yang terlihat dari pandangan atas. Pada gambar 6 (a) terlihat intensitas turbulensi pada plain airfoil. Berdasarkan gambar tersebut tampak perbedaan karakteristik turbulensi pada permukaan atas. Pada plain airfoil terlihat perbedaan warna secara gradual dari leading edge hingga trailing edge. Warna hijau menunjukkan intensitas turbulensi yang relatif tinggi terdapat pada daerah leading edge, lalu menurun secara gradual hingga turbulensi terendah yang ditunjukkan dengan warna biru tua dan biru muda pada daerah trailing edge.

Sedangkan gambar 6.(b) dan (c) karakteristik turbulensi airfoil dengan vortex generator terlihat memiliki warna yang dominan lebih tinggi daripada plain airfoil. Perubahan warna secara gradual dari leading edge hingga trailing edge tampak jelas. Perbedaan dari gambar tersebut yaitu pada airfoil dengan vortex generator memiliki tingkat turbulensi yang lebih tinggi dengan ditandai dengan warna biru muda yang lebih dominan serta warna biru tua pada daerah trailing edge terlihat berkurang. Sehingga dapat disimpulkan vortex generator pada permukaan atas airfoil mampu meningkatkan intensitas turbulen hingga ke daerah trailing edge. 


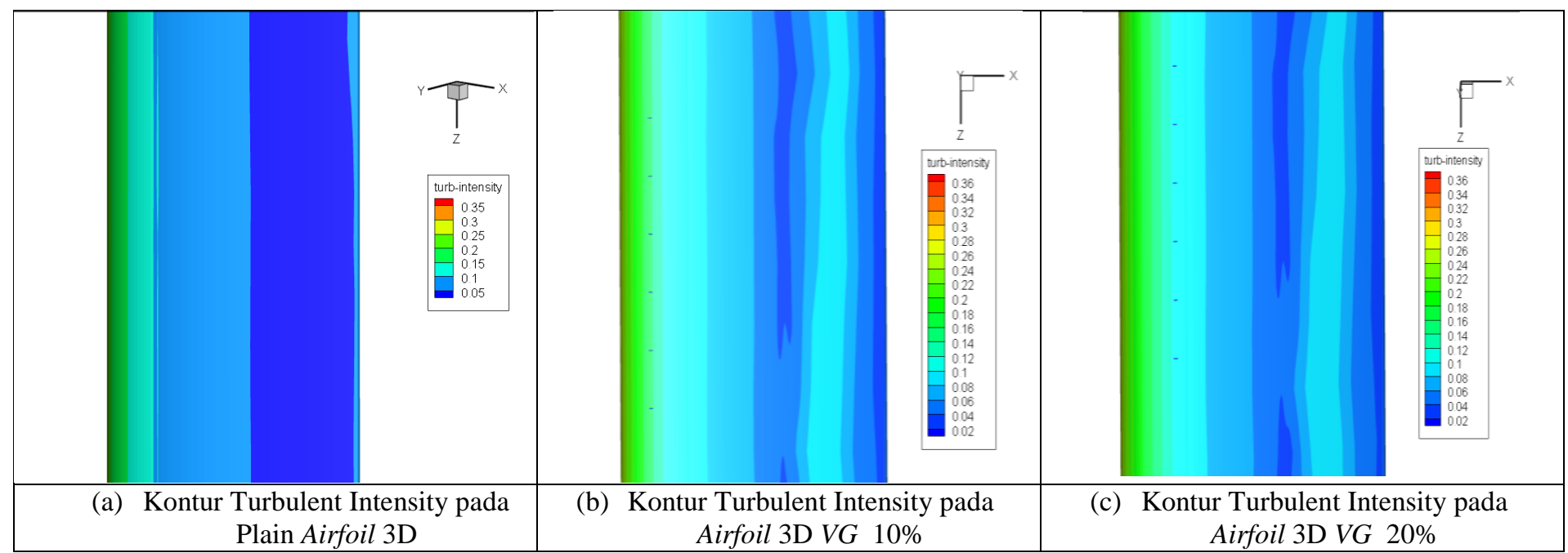
Plain Airfoil 3D Airfoil 3D VG $10 \%$ Airfoil 3D VG 20\%

Gambar 6. Visualisasi perbandingan turbulent intensity pada sudut serang $19^{0}$ tanpa $V G, V G 10 \%$ dan $20 \%$

\section{KESIMPULAN}

Dari penelitian ini maka dapat ditarik kesimpulan antara lain:

1. Separasi akan semakin maju dekat leading edge seiring dengan bertambahnya sudut serang dan bilangan Reynolds yang kecil pada sudut serang yang sama. Separasi menentukan besar kecilnya wake, apabila separasi yang terjadi lebih awal maka wake yang terbentuk akan semakin besar. Pada gambar $3, \alpha=19^{0}$ terlihat bahwa titik separasi semakin maju mendekati leading edge.

2. Dengan adanya vortex generator dapat menambah momentum aliran yang melewatinya sehingga aliran masih mengikuti kontur upper surface. Momentum aliran yang tinggi mampu melawan gaya geser dan adverse pressure gradient.

3. Dengan penambahan vortex generator maka Turbulence Kinetic Energy di permukaan airfoil lebih tinggi dari pada plain airfoil dilihat dari gradient warna.

\section{DAFTAR PUSTAKA}

[1] Lin, J. C. 2002. Review of Research on Low Profile Vortex Generator to Control Boundary Layer separation. Progress in Aerospace Science 38 : 389-420.

[2] Anand, U., Shudakar, Y., Thileopanragu, R., Gopinathan, V.T., dan Rajasokar, R. 2010. Passive Flow Control Over NACA 0012 Airfoil Using Vortex Generator. India: Department of Aerospace Engineering IIT Madras.

[3] Zhen, Tan Kar, Ahmad, Kamarul Arifin., Zubair, Muhammed.,(2010), Experimental and Numerical Investigation of the Effects of Passive Vortex Generators on Aludra UAV Performance, Journal of Aeronautics, School of Aerospace Engineering, University Sains Malaysia, Nibong Tebal 14300, Malaysia

[4] Anderson, John D. Jr. 1988. Fundamental of Aerodynamics. Singapore : McGraw-Hill, Inc.

[5] H. Shan et al.(2007), Numerical Study of Passive and Active Flow Separation Control Over NACA 0012 Airfoil, Science Direct

[6] Mulvany, Nicholas et. al.(2004), Steady State Evaluation of Two Equation RANS Turbulence Models for High Reynolds Number Hydrodynamic Flow Simulations 